\title{
血友病 $\mathrm{A}$ 患者に発症した膵内血腫の 1 例
}

\author{
国立病院機構大阪医療センター外科 \\ 末 田聖倫辻江正徳宮本敦 史 \\ 三嶋秀行 中森 正二 辻 仲 利 政
}

症例は62歳，男性. 併存疾患に血友病 $\mathrm{A}$ があるが，第VIII因子製剤の投与が不定期であ った.上行結腸癌術後 2 力月目の腹部造影 CT で膵頭部に $20 \mathrm{~mm}$ 大の周囲が low density で内部に造影効果を有する腫瘤を認めた。腫瘤は徐々に増大傾向であり，非機能性膵内 分泌腫瘍を疑い，覀全胃温存膵頭十二指腸切除術を施行した。術前および術後は日本血 栓止血ガイドラインに沿って第VIII因子製剂を使用した。切除標本では膵頭部に $28 \times 20 \times$ $20 \mathrm{~mm}$ 大の血腫様結節を認めた。組織学的には悪性所見は認められず，赤血球主体の新 鮮血液成分からなる血腫を内容とする囊胞様拡張領域がみられ, 膵内血腫と診断した。 血友病の患者で造影効果を有する腫瘤の出現を認めた際には, 血腫も鑑別疾患の一つと 考える必要がある.

索引用語：血友病，膵臓，血腫

はじめに

腹腔内血腫は，多くが腹部鈍的外傷に起因すること が多い. しかし，抗凝固療法を受けている患者や出血 性素因を有する患者では，外傷を伴わずに発症するこ とがある ${ }^{1)}$. 今回われわれ，血友病を併存疾患にもち， 非機能性膵内分泌腫瘍と鑑別が困難であった膵内血腫 の 1 例を経験したので報告する.

\section{症例}

症例：62歳，男性.

主訴：特記事項なし。

併存疾患：血友病 A.

既往歴：2010年 7 月に上行結腸癌（cT1N0M0stage IA）に対して腹腔鏡下右半結腸切除術を施行した。

現病歴：血友病 A を併存疾患にもつが, 第VIIII因子製 剤の投与が不定期であった。2010年 7 月に上行結腸癌 にて腹腔鏡下右半結腸切除術を行い，その 2 力月後の 腹部 CT で膵頭部に上行結腸癌手術前の腹部 CT では 認めなかった $20 \mathrm{~mm}$ 大の腫瘤を認め, MRI でも同部位 に腫瘤を認めた。腫瘤は増大傾向にあり，膵内分泌腫 瘍を疑い，手術目的で入院した。

2011年 6 月 24 日受付 2011 年 8 月 4 日採用

\section{〈所属施設住所〉}

于540-0006 大阪市中央区法円坂 2-1-14
入院時現症：身長 $160 \mathrm{~cm}$ ，体重 $64.2 \mathrm{~kg}$. 体表リンパ 節は触知しなかった。黄疸は認めなかった。胸部理学 的所見に異常所見は認めなかった。腹部には大腸癌術 後の手術痕を認めた。

血液検査：Hb $12.3 \mathrm{~g} / \mathrm{dL}$ と軽度貧血を認めた。第VIII 因子 3,500 単位ボーラス投与後の第VIII因子活性は $79 \%$ で，APTT は45秒であった。第VIII因子投与前の凝固能 は, APTT が69.2秒で，PT 活性が115\%であった。各

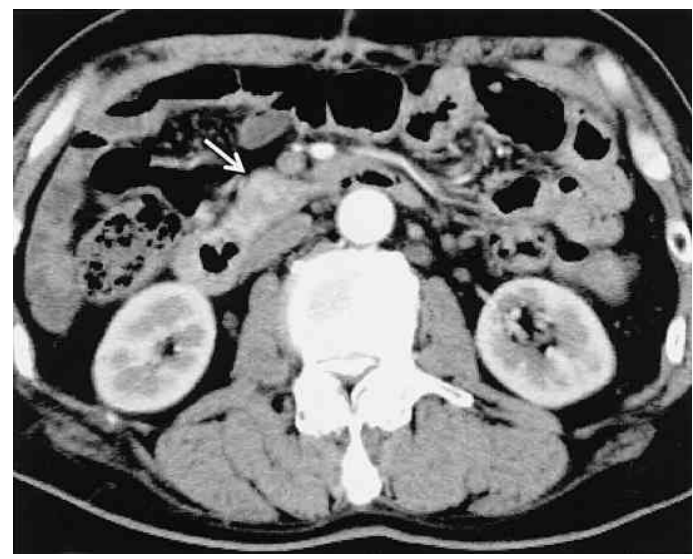

Fig. 1 : Dynamic computed tomography (CT) scan of the pancreas shows an enhanced lesion in the pancreatic head (arrow). 

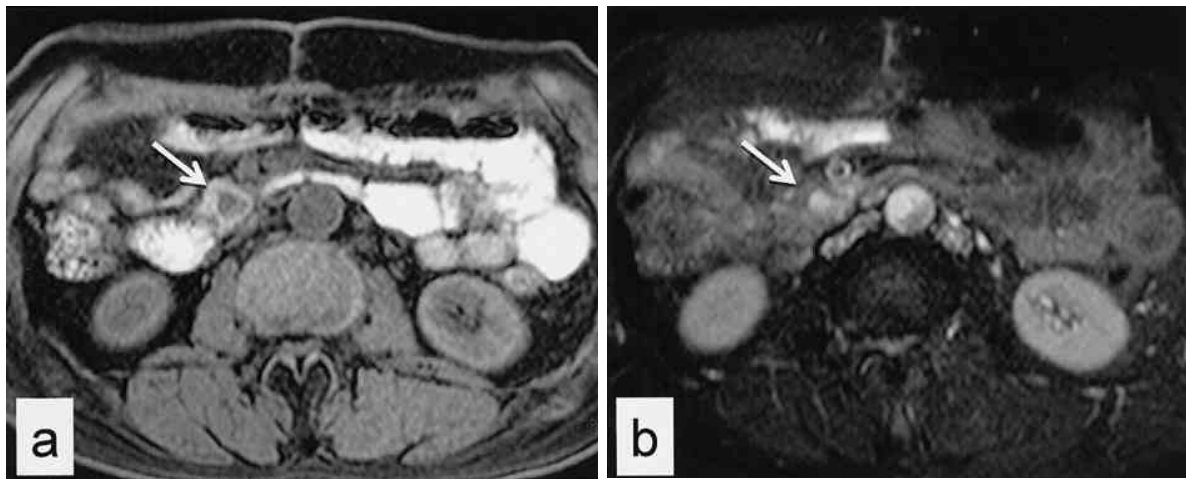

Fig. 2 : Magnetic resonance (MR) imaging shows a lesion (about $20 \mathrm{~mm}$ in size, arrow) in the pancreatic head. (a) low-intensity T1-weighed image, (b) high-intensity T2-weighed image.
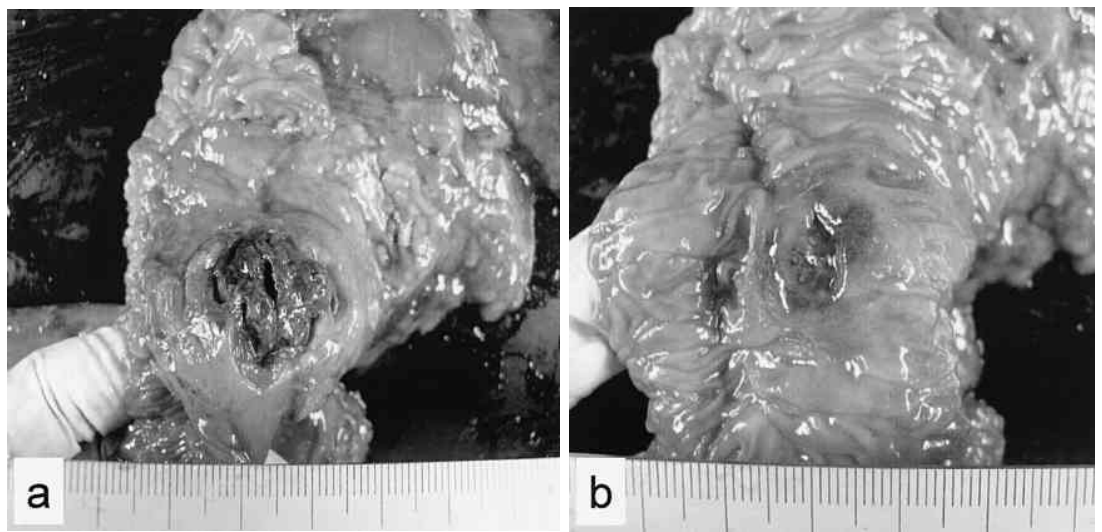

Fig. 3 : (a) The resected tissue shows a hematoma $(20 \times 28 \times 20 \mathrm{~mm})$ in the pancreatic head. (b) The hematoma in the pancreatic head ruptures into the duodenum.

種ホルモン検査や腫瘍マーカーに異常所見は認めなか つた.

膵臓ダイナミック CT (Fig. 1) : 膵頭部に $20 \mathrm{~mm}$ の 周囲が low density で内部に造影効果を有する腫瘤を 認めた。主膵管や総胆管に拡張を認めなかった。

腹部 MRI（Fig. 2a， b）：膵頭部に20mm 大の T2 強調画像で高信号, T1強調画像で低信号, high-intensity diffusion-weighted image で高信号の腫瘤を認めた。

以上の検査結果から，非機能性膵内分泌腫瘍と診断 し，手術を施行した。

手術所見：血友病 A が併存疾患にあるため, 硬膜外 麻酔は行わず，全身麻酔下にて手術を行った。上中下 腹部正中切開にて開腹した。腹腔内に遠隔転移や腹膜 播種病変は認めなかった。ダグラス窩の洗浄細胞診も
悪性所見を認めなかった。手術は亜全胃温存膵頭十二 指腸切除およびII型再建（膵，胆管，胃の順に吻合） を施行した。手術時間は497分,出血量は $540 \mathrm{ml}$ であった。 切除標本肉眼的所見（Fig. 3a, b) : 肉眼的には膵 頭部に大きさ $28 \times 20 \times 20 \mathrm{~mm}$ 大の血腫様結節を認め た。病変は膵実質から十二指腸筋層にかけて圧排性に 占居・進展していた。

病理組織学検査所見（Fig. 4a, b)：組織学的には 赤血球主体の新鮮血液成分から成る血腫を認めた。内 腔を裏打ちするような上皮細胞成分はみられず，腔の 壁は核型不整を示す線維芽細胞などの幼弱な間葉系細 胞やへモシデリン沈着，小型血管の増生，リンパ球主 体の炎症細胞浸潤を含む結合織で構成されていた。内 分泌腫瘍や上皮性腫瘍を示唆する所見は認めず，膵内 

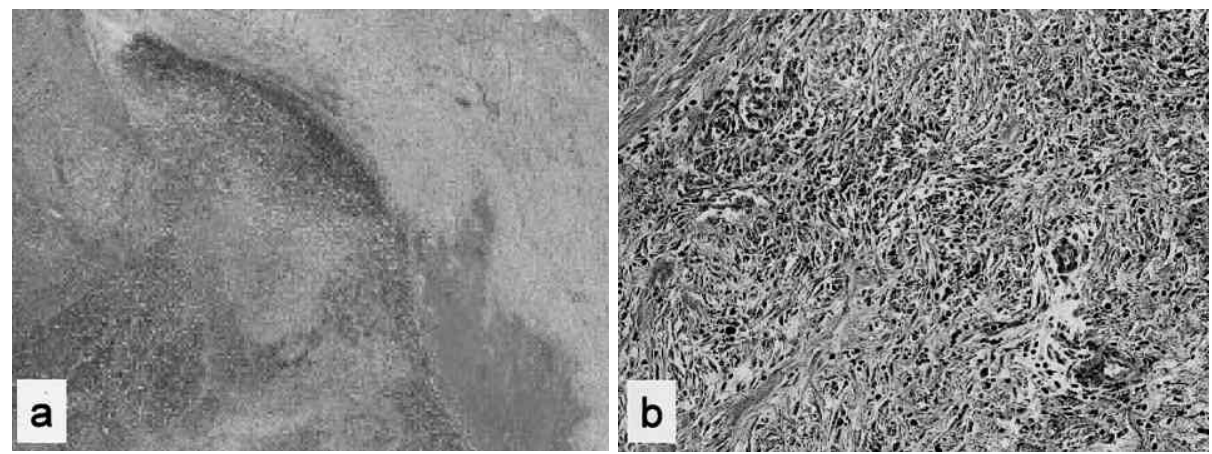

Fig. 4 : (a ) Microscopic analysis revealed a hematoma (hematoxylin and eosin (H.E.) staining, $\times 40)$ and $(\mathbf{b})$ hemosiderin deposition (H.E. staining, $\times 100$ ).

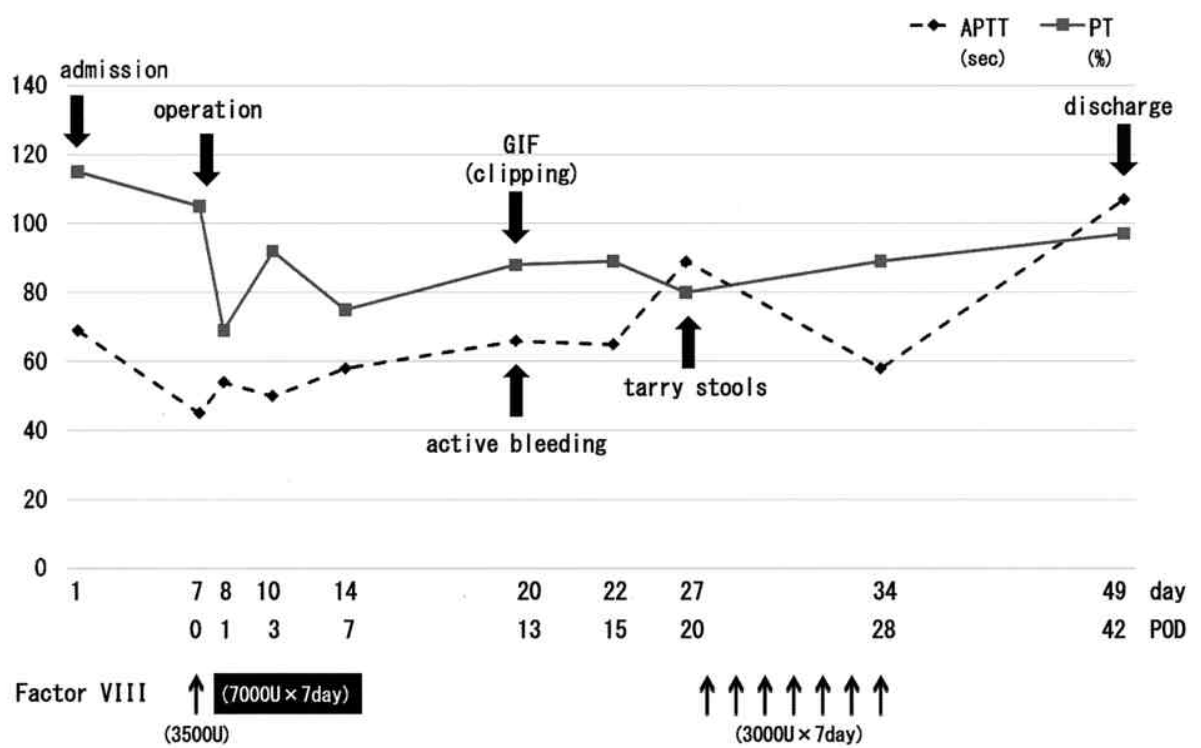

Fig. 5 : Clinical course.

血腫と䛦断した。

術後経過（Fig. 5)：血友病 A が併存疾患にあるた め,術前に第VIII因子製剤を 3,500 単位ボーラスで 1 回輸 注後，290単位/hr（7,000単位/日）を術後第 7 病日ま で日本血栓止血学会のガイドライン通り施行した。術 後第12病日に高度の貧血を認め，緊急内視鏡を施行し た. 結果，露出血管を伴う消化管出血が再建を行った 空腸空腸吻合部の輸出脚側の口側腸管に認められた

(Fig. 6).内視鏡下にてクリップによる止血を行い, 日本血栓止血学会のガイドラインに沿って第VIII因子製 剤の投与を行い改善した。以後問題ないため，第42病 日に退院した。
考 察

血友病は血液凝固異常の第VIII因子あるいは第IX因子 の凝固活性が先天的に欠乏しているため，出血傾向を 呈する疾患である。伴性劣性遺伝の比較的まれな疾患

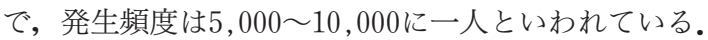
また凝固因子インヒビターを有する後天性血友病が, 悪性腫瘍や妊娠を要因として発症することも報告され ている2)3.

われわれが，医学中央雑誌にて「血友病」，「膵臓」， 「血腫」をキーワードに1983年から2010年まで検索を 行ったところ，同様の報告例はなく，またPubMedに て「hemophilia」,「pancreas」,「hematoma」をキー 


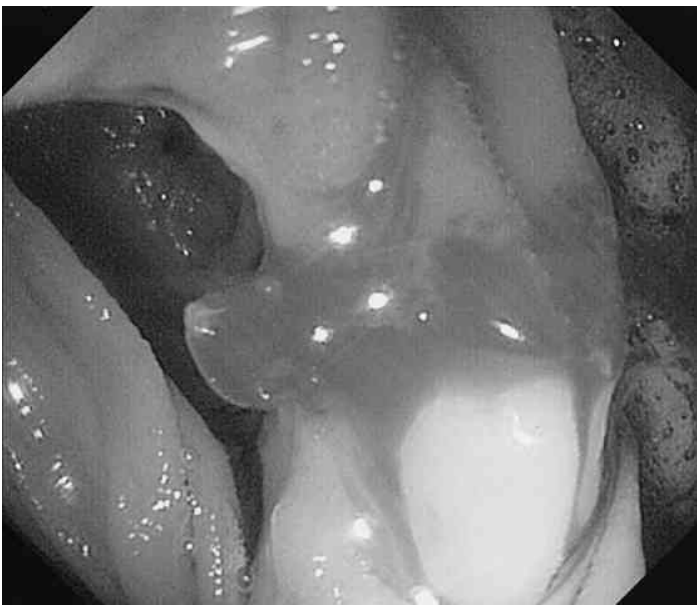

Fig. 6: Emergency gastrointestional fiberoptic (GIF) endoscopy showed upper gastrointestinal bleeding.

ワードに2010年まで英文論文で検索しても，同様の報 告例は認めず，本症例が 1 例目の報告と考えられた。 本症例は動脈瘤や動静脈奇形などの出血素因は認めら れず，膵内で出血した原因は不明であった。しかし， 第VIII因子製剤の在宅注射が本人の判断のもと，およそ 2 - 3 力月に 1 回の頻度で不定期に投与していた経緯 があり, それが出血傾向を助長し, 膵内血腫の発症原 因となった可能性はある。また初回手術が腹腔鏡下右 半結腸切除術であり，手術時の物理的な刺激が血腫の 原因となった可能性も否定できない. 血腫であれば， 保存的治療に反応し縮小することから，悪性腫瘍との 鑑別が可能な場合もあるため, 血友病の患者で造影効 果を有する腫瘤の出現を認めた際には血腫も鑑別疾患 の一つとして考える必要があると思われた。

血友病患者に対する手術は第VIII因子製剂の補充，周 術期の第VIII因子活性のモニタリングにより, 安全に行 えると報告されている ${ }^{4) 5)}$. 血友病患者の手術時には凝 固因子製剤の投与が必要であり，2008年の日本血栓止 血学会のガイドラインでは，インヒビターのない血友 病患者の全身麻酔下開腹手術の場合は，凝固因子製剂 の持続輸注をトラフ因子レベル80～100\%を目標とし て，5-10日間することを推奨している ${ }^{6}$. 本症例でも 日本血栓止血学会のガイドラインに則ってトラフ因子 レベル $80 〜 100 \%$ を目標として術前および術後 7 日間 第VIII因子製剤を使用した。

本症例は第VIII因子製剂投与患者の合併症報告例であ る. 術後合併症として, 術後第12病日に空腸空腸吻合
部の輸入脚側の口側空腸からの出血を認めた。過去に は, 術後合併症として血腫によるイレウスを発症した 症例 ${ }^{778)}$, 後出血をきたした症例 ${ }^{9)}$, 本症例に類似した空 腸空腸吻合部から出血した症例 ${ }^{10)}$, 食道胃接合部付近 に発症した潰瘍出血の症例 ${ }^{3)}$ が報告されており, 第VIII 因子製剤の投与が終了した術後 1 週間以上経過しても 注意深く経過観察を行い, 凝固因子製剂の投与の有無 を管理する必要があると考える。

今後, 同様の腹腔内出血をきたさないようにするた め, 本症例では第VIII因子製剤の在宅注射を定期的に投 与しているか確認できるように，手帳を渡して記録す るように指導している。

\section{謝辞}

病理学的検討, 診断にご協力いただいた国立病院機 構大阪医療センター臨床検査科, 真能正幸先生, 芝郁 恵先生に深く感謝致します。

\section{文 献}

1）小泉 沢，鈴木 潤，藤江弘美他：血友病 $\mathrm{A}$ 患児 に発症した非外傷性十二指腸壁内血腫に対する保 存的治療の経験. 日小児救急医会誌 $2008 ； 7$ ： $173-179$

2) 田中一郎, 天野景裕, 㴰 正志他：わが国におけ る後天性凝固因子インヒビターの実態に関する 3 年間の継続調査 予後因子に関する検討. 日血栓 止血会誌 $2008 ； 19 ： 140-153$

3）坂本 薰, 岡本春彦, 田中 亮他：胃癌術後に発 症した後天性血友病の 1 例. 日臨外会誌 2009 ; $70: 3005-3010$

4) Rudowski WJ, Scharf R, Ziemcki JM : Is major surgery in hemophiliac patients safe? World J Surg $1987 ; 11: 378-386$

5）鈴木隆史，福武勝幸：出血性素因を示す血液疾患 患者の周術期管理 先天性凝固異常症に対する手 術. 血液フロンティア $2005 ； 15 ： 1649-1659$

6）松下 正, 天野景裕, 瀧 正志他：インヒビター のない血友病患者の急性出血, 処置・手術におけ る凝固因子補充療法のガイドライン. 日血栓止血 会誌 $2008 ； 19 ： 510-519$

7）今村史人, 丸森健司，神賀正博他：大腸癌術後腹 腔内血腫によるイレウスを契機に診断された血友 病 A の 1 例. 日臨外会誌 $2010 ； 71 ： 1343-1346$

8) Onda M, Urazumi K, Abe R, et al : Obstructive ileus caused by blood clot after emergency total gastrectomy in a patient with hemophilia 
A. Surg Today $1998 ; 28: 1266-1269$

9) 留奥 誠, 久藤 真, 津田雅之他：血友病手術患 者 7 例の検討. 臨血 $1983 ; 24: 232-241$
10）市川英幸，田中聡行，池野龍雄他：血友病 A に合 併した残胃癌の 1 例. 日臨外会誌 $2003 ; 64: 874$ $-878$

\section{PANCREATIC HEAD HEMATOMA IN A CASE WITH HEMOPHILIA A}

Toshinori SUEDA, Masanori TSUJIE, Atsushi MIYAMOTO, Hideyuki MISHIMA, Shoji NAKAMORI and Toshimasa TSUJINAKA

Department of Surgery, National Hospital Organization Osaka National Hospital

The patient was a 62 -year-old man with hemophilia A who received factor VIII infusions at irregular intervals. He underwent laparoscopic right hemicolectomy in July 2010 for ascending colon cancer. In September 2010, follow-up abdominal enhanced computed tomography (CT) and magnetic resonance imaging (MRI) showed an enhanced lesion $(20 \mathrm{~mm}$ in diameter) in the pancreatic head. The mass had enlarged, and hence, we diagnosed an islet cell tumor of the pancreas. Subtotal stomach-preserving pancreaticoduodenectomy by the modified Chiled method was performed. The patient was administered one-shot and continuous infusion of factor VIII during the perioperative period, as per the guidelines of the Japanese Socienty on Thrombosis and Hemostasis. The pancreatic mass $(28 \times 20 \times 20 \mathrm{~mm})$ was found to be a hematoma. Herein, we describe this hematoma in the pancreatic head in a patient with hemophilia A. When a patient with hemophilia has an enhanced mass, the possibility of hematoma should be considered.

Key words : hemophilia, pancreas, hematoma 